\title{
Thirty-year land elevation change from subsidence to uplift following the termination of groundwater pumping and its geological implications in the Metropolitan Taipei Basin, Northern Taiwan
}

\author{
Chih-Tung Chen ${ }^{\mathrm{a}, *}, \mathrm{Jyr}^{-C h i n g ~} \mathrm{Hu}^{\mathrm{a}}$, Chia-Yu Lu ${ }^{\mathrm{a}}$, Jian-Cheng Lee ${ }^{\mathrm{b}}$, Yu-Chang Chan ${ }^{\mathrm{b}}$ \\ a Department of Geosciences, National Taiwan University, Taipei 106, Taiwan, ROC \\ ${ }^{\mathrm{b}}$ Institute of Earth Sciences, Academia Sinica, Taipei 115, Taiwan, ROC
}

Received 12 February 2007; received in revised form 16 August 2007; accepted 4 September 2007

Available online 21 September 2007

\begin{abstract}
Several levelling routes in the metropolitan Taipei Basin have been repeatedly conducted during the past decades, mainly in order to monitor the anthropogenic ground subsidence due to massive pumping of groundwater. We analysed the levelling data released from government and investigated the rate of ground level change from 1975 to 2003, which postdate the massive groundwater exploitation in Taipei area. Based on the contour maps created from the levelling data of 406 benchmarks, the overall subsidence rate in the Taipei Basin gradually decreased since 1975, and around 1989 the basin switched to slight uplift throughout a large part of the basin. Three mechanisms are proposed to be responsible for the observed land elevation changes, including shallow soil compaction, deformation within aquifer, and tectonic subsidence. The trend of the ground level change in 1975-2003 essentially demonstrated the effects of natural recharge to previously depleted aquifers, and is explained by the hydro-mechanical coupling of aquifer materials, i.e., elastic rebound, to the rising piezometric level. The rate of shallow soil compaction is estimated about $1-8 \mathrm{~mm} / \mathrm{yr}$ throughout the basin according primarily to the shallow clay thickness. Asymmetric tectonic subsidence related to the Shanchiao Fault was estimated to be $1.75 \mathrm{~mm} / \mathrm{yr}$ and $0.9 \mathrm{~mm} / \mathrm{yr}$ in the western part and the central part of the basin, respectively. By subtracting the components of the soil compaction and tectonic subsidence from the surface land elevation change, the rebound of aquifer strata was estimated to be about $6.7 \mathrm{~cm}$ and $16 \mathrm{~cm}$ in western margin and Central Taipei, respectively. The amount of rebound is approximately $10 \%$ in magnitude comparing to the amount of previous anthropogenic subsidence due to massive groundwater pumping, totally about $2 \mathrm{~m}$.
\end{abstract}

(C) 2007 Elsevier B.V. All rights reserved.

Keywords: Groundwater pumping; The Taipei Basin; Ground subsidence; Aquifer deformation; The Shanchiao Fault

\section{Introduction}

Excessive groundwater utilization in agricultural and urban area is known to cause rapid human-induced land

\footnotetext{
* Corresponding author. Tel.: +886 2 33662927; fax: +886223636095

E-mail address: kthomasch@gmail.com (C.-T. Chen).
}

subsidence and pose severe problems including damage to building and infrastructures, exhaustion of groundwater resources, increase of risks of inundation, and inland sea water intrusion, as documented in many places around the world (e.g. Bangkok, Thailand, Phienwej et al., 2006; Jakarta, Indonesia, Abidin et al., 2001; Ravenna, Italy, Teatini et al., 2005; Pingtung Plain, 
Taiwan, Hu et al., 2006). Pumping-induced subsidence is resulted primarily from irreversible compaction of aquitard material composed of fine-grained silt and clay layers during prolonged drainage process, and from minor amount of presumably elastic compaction from compression of coarse-grained conglomerate and sand deposits in aquifers (Holzer, 1984; Waltham, 2002). Ground surface change due to pumping generally reflects the response to dropping piezometric level (Fig. 1). Ban or controls on pumping are the actions usually taken by many authorities to mitigate the hazards, and regional groundwater table rises accordingly due to natural groundwater recharge. Ground elevation change during groundwater recovery after long-term extensive pumping should exhibit some amount of uplift. This effect is considered to be originated from relaxation of elastically compressed aquifer materials when pore pressure regained, as illustrated by injection experiment carried out at the severely subsided Wilmington oilfield in the Long Beach harbour area of California (Allen and Mayuga, 1969), a phenomenon commonly referred as elastic rebound (Waltham, 2002). Characterization of such post-pumping behaviour, however, has not yet been studied in detail.

Typical ground response during fast artificial recharge for short-period pumping tests (e.g. Cappa et al., 2005) is well known as curve A in Fig. 1, indicating immediate and direct coupling of changes between ground elevation and hydraulic head. On the other hand, ground surface variations following cessation of prolonged groundwater pumping are mainly characterized by a transition of minor movements from subsidence to uplift (curve B in Fig. 1), as reported in Venice, Italy (e.g., Gatto and Carbognin, 1981). It demonstrates a more complicated scheme when groundwater production is of greater spatial and temporal scales. Characteristics and mechanisms of regional land elevation

\section{Ground level change}

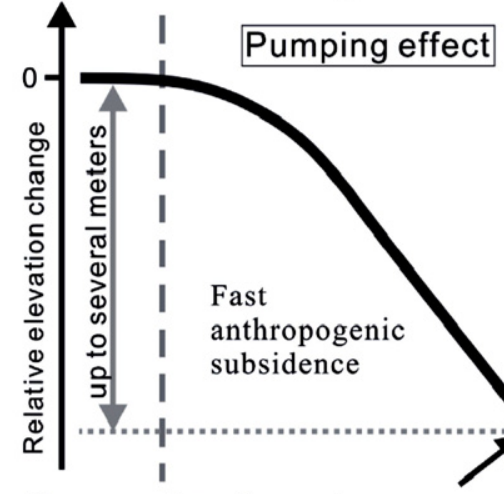

\section{Aquifer water level}

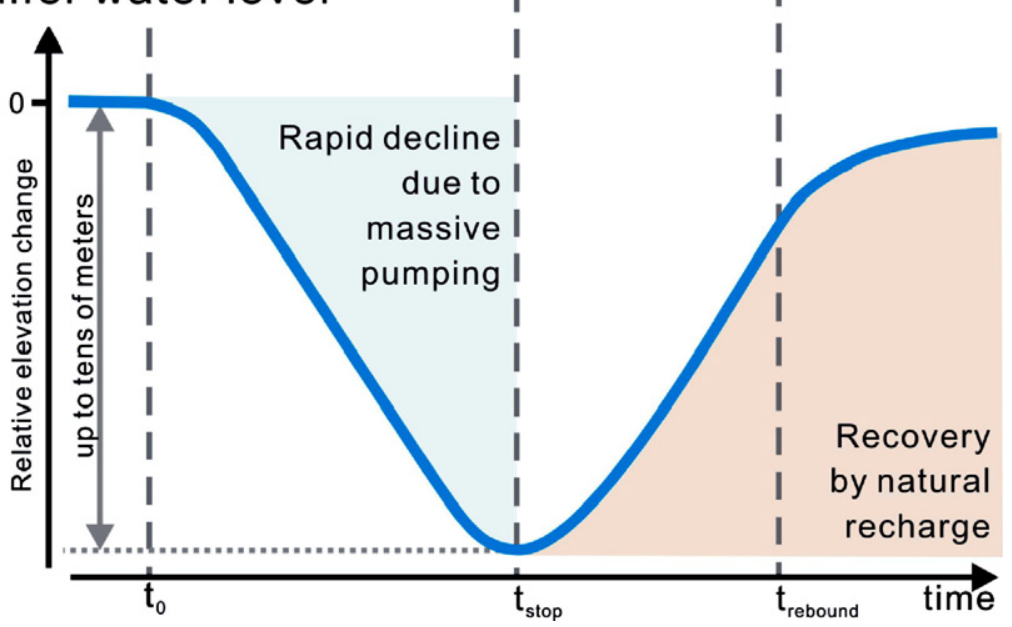

Fig. 1. General conceptual model of ground elevation change due to artificial piezometric head drawdown and recovery. Note that two different postpumping behaviours of ground level change: (a) short-term pumping test and (b) long-term artificial pumping. See text for details 
change, particularly the elastic rebound after experiencing basin-wide groundwater over-extraction, remain unclear. The history of pumping and recovery of the groundwater in the Taipei Basin in northern Taiwan, therefore, provides a good opportunity for better understanding of this post-pumping mechanism.

The Taipei City is the political and economical centre of Taiwan (Fig. 2a) with dense population of about 3 million habitation and another several million inhabitants in the surrounding suburban areas. Like many big cities in the world, early development of the Taipei city was partly facilitated by its rich groundwater resources. However, unrestriction of groundwater over-pumping resulted in both dry-ups of wells and severe land subsidence, especially during 1955-1970 (Hwang and $\mathrm{Wu}, 1969 ; \mathrm{Wu}, 1987)$. In order to prevent more ground subsidence and further associated damage, the government put a stop on the use of groundwater in the Taipei Basin during the early 1970s. Rapid land subsidence has therefore significantly decreased (Wu, 1987), and the groundwater table was gradually recovered and became approximately stable since late 90s (Chia et al., 1999; Fig. 3c). In this paper, we intend to examine recent vertical change of ground surface in response to the post-pumping groundwater recharge in more details. Thanks to several annually measured levelling routes

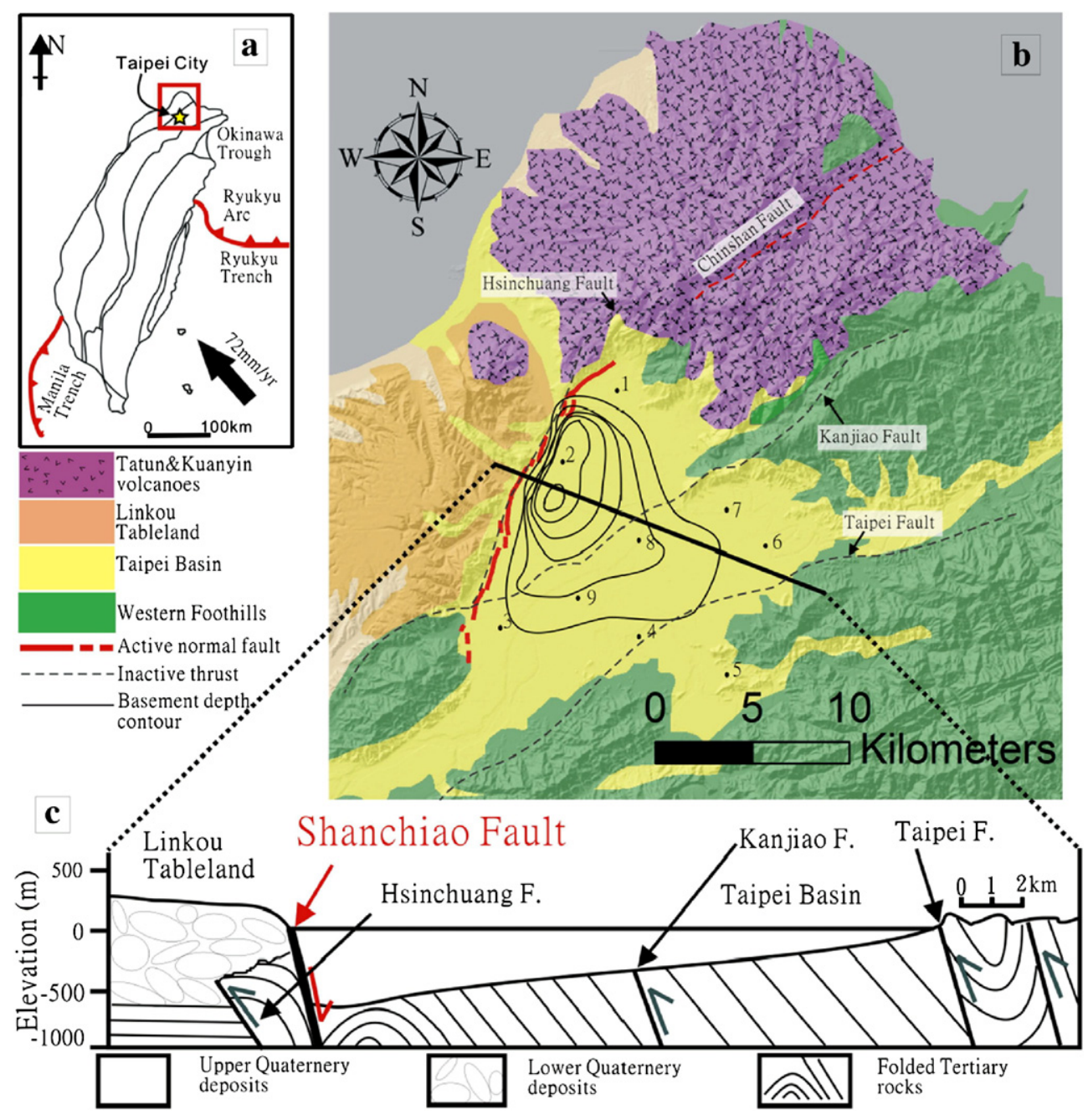

Fig. 2. (a) Tectonic framework of Taiwan. The converging rate and direction of Philippine Sea Plate relative to Eurasia plate is adapted from Yu et al. (1999b) and Zang et al. (2002). (b) Four geological domains of Taipei area (see text for details). The thin grey lines within the Taipei Basin are the basement depth contour of $100 \mathrm{~m}$ interval (after Teng et al., 2001). The red line along the western margin of the Taipei Basin is the Shanchiao Fault (after Chen et al., 2006). The black dots mark local district names in the Taipei Basin: 1. Guandu, 2. Wuku, 3. Shulin, 4. Zhonghe, 5. Jingmei, 6. Sungshan, 7. Dazhi, 8. central Taipei, 9. Banchiao. (c) Simplified geological cross section of the Taipei Basin (modified from Teng et al., 1999). The Hsinchuang, Kanjiao, and Taipei Faults are inactive thrust faults (denoted with grey arrows) which slipped during the collision phase in the Taipei area. 
across the Taipei Basin, we are able to reconstruct the history of the land vertical change following the recharge of the aquifers.

Furthermore, while severe anthropogenic land subsidence has been stopped in the Taipei metropolitan area, concerns on potential earthquakes and related geohazards due to possible reactivation of the active
Shanchiao fault continue to be discussed (e.g., Teng et al., 2001; Shyu et al., 2005; Huang et al., 2007). Taiwan is situated in a plate boundary between the actively converging Eurasian and Philippine Sea plates beginning about $5 \mathrm{Ma}$ (Suppe, 1981; Teng, 1990). At present, the collision process is manifested in southern and central Taiwan as demonstrated by the intense
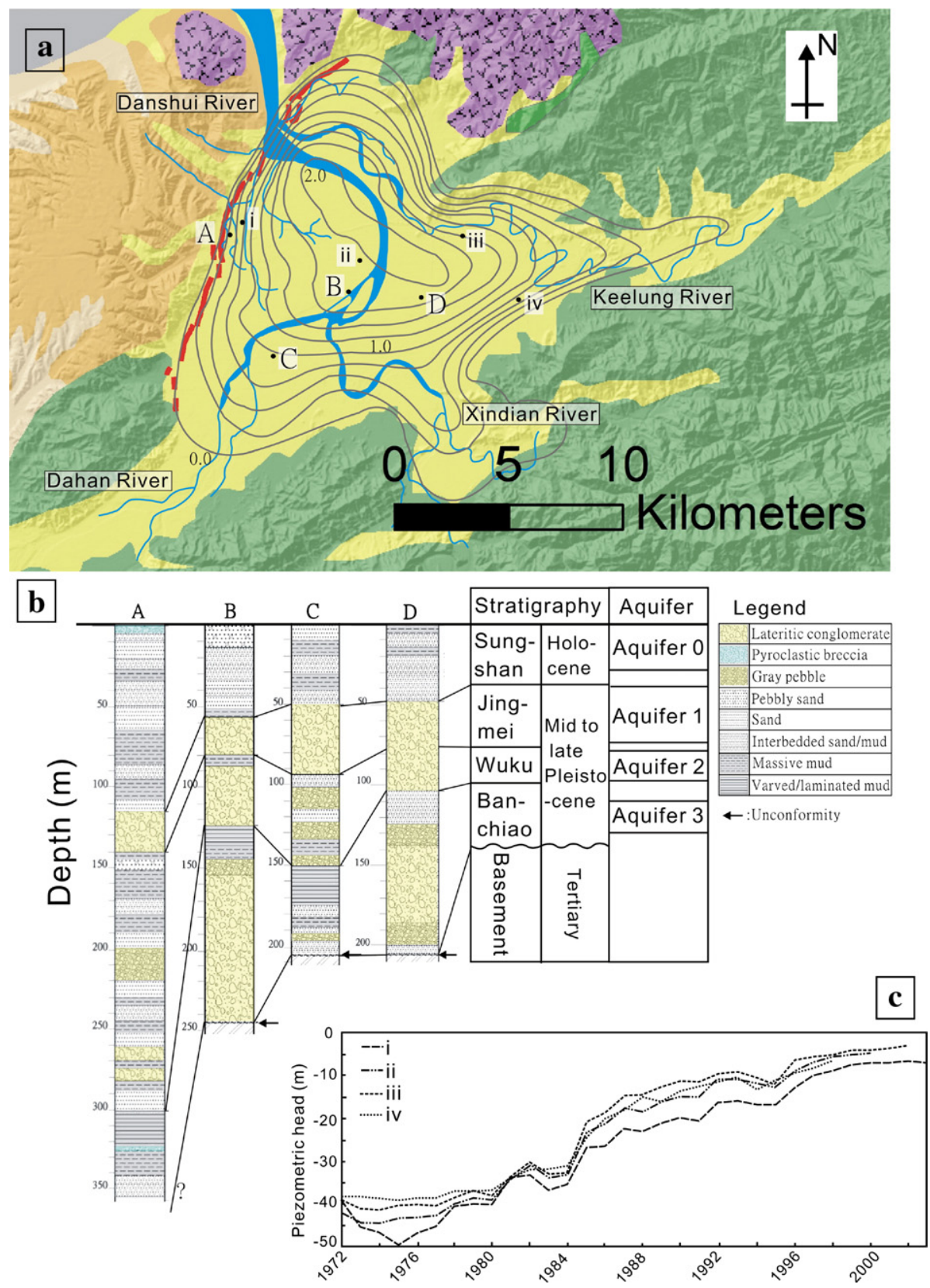

Fig. 3. (a) Cumulated subsidence in the Taipei Basin from 1955 to 1991 (after Lin et al., 1999). Contour interval is 0.25 m. Borehole sites: A: Wuku (WK-1), B: Sanchung (SC-1), C: Banchiao (PC-2), D: Shingongyuan (Shingongyuan No.1). Groundwater monitoring wells: i: Wuku, ii: Sanchung, iii: Shingtien Palace, iv: Sungshan. (b) Stratigraphic architecture of late-Quaternary deposits within the basin, along with the four aquifers (modified from Teng et al., 1999). (c) Piezometric head records of Aquifer 1 at four monitoring wells since 1972 to 2003 (Chia et al., 1999; Cho, 2006). 
crustal shortening, according to data from the GPS and seismic networks of Taiwan. In contrast, north-eastern Taiwan underwent post-collisional processes and has been considered to be incorporated in the opening of the southern Ryukyu back-arc system (Teng et al., 2000), as evidenced by the presence of Quaternary extensional structures (Lee and Wang, 1988; Lu et al., 1995) and extensional earthquake focal mechanisms (Yeh et al., 1991; Kao et al., 1998). The Shanchiao Fault, which bounds the western edge of the Taipei Basin, has attracted attention in terms of earthquake hazards during the last decades. Tectonic subsidence related to this possible active fault is illuminated through recent levelling data, and should have an influence on the land elevation change in the Taipei Basin especially in the western part.

Levelling data in the Taipei area from 1975 to 2003 postdating the massive groundwater exploitation is utilized in the present study to examine the general conceptual model relating ground level response to recharge of aquifers. The various depth-related processes responsible for the observed occurrences of subsidence and uplift are discussed, including shallow soil compaction, crustal-scale tectonic movement, and irreversible compaction and elastic rebound within aquifer. A schematic model explaining recent 30 years land elevation change in the Taipei Basin is proposed.

\section{Regional setting}

\subsection{Geological background}

The Taipei region can be divided into four geological domains (Fig. 2b): (1) the Foothills, hilly terrains north, east, and south of the Taipei Basin, consisting of foldand-thrust belt of Miocene continental margin sedimentary packages; (2) the Tatun and Kuanyinshan volcanoes, north and northwest of the Taipei Basin, piled up of late-Quaternary andesitic volcanic formations; (3) the Linkou Tableland, west of the Taipei Basin, covered by Quaternary thick lateritic conglomerates as an ancient fan-delta which rests above Miocene/Pliocene sedimentary rocks (Chen and Teng, 1990); (4) the Taipei Basin, a triangular-shaped half-graben filled with late-Quaternary fluvial deposits since about $0.4 \mathrm{Ma}$ (Wei et al., 1998; Teng et al., 2001), which lie uncomformably over the deformed Miocene sedimentary packages.

The late-Quaternary deposits of the Taipei Basin form an asymmetric wedge shape in thickness: reaching a maximum depth of about $700 \mathrm{~m}$ in the western margin and gradually becoming thinner toward the east and south (Fig. 2c). These unconsolidated deposits in the
Taipei Basin are divided into four lithostratigraphic units (Teng et al., 1999), from bottom to top (Fig. 3b): (1) the lowest Banchiao formation, consisting of fluvial sand, mud and conglomerates, with minor pyroclastic debris and thick varved mud in the upper section; (2) the Wuku formation, consisting of fluvial sand and conglomerates with minor mud and lateritic conglomerates; (3) the Jingmei formation, comprising of lateritic alluvial-fan conglomerates; (4) the Sungshan formation, composed of estuary interbedded sand-mud deposits. The basin deposits are marked by prominent facies changes and most of the sedimentary layers laterally pinch out rapidly. However, the widespread lateritic gravel of the Jingmei formation and the varved layers in upper Banchiao formation serve as basin-wide marker beds (Teng et al., 1999).

Brief geological evolution of the Taipei Basin is summarized in the following, based on previous studies. In Pliocene, the Taiwan Orogeny has initiated as the Luzon Arc of the Philippine Sea plate approaching to continental margin of Eurasia (e.g. Suppe, 1981). The Miocene shallow marine sedimentary rocks of the Taipei area were deformed into imbricated fold-and-thrust sheets with several major faults including the Hsinchuang, Kanjiao, and Taipei Faults (Fig. 1b, c) as mountainous ranges (Ho, 1975; Wang-Lee et al., 1978). While the orogeny reached climax in northern Taiwan about $2 \mathrm{Ma}$, the Paleo-Tanshui River, the major river in the Taipei Basin, produced the Linkou fan-delta around the ancient mountain front thrust (Chen and Teng, 1990), the Hsinchuang Fault which runs approximately parallel to the western margin of the Taipei Basin (Teng et al., 2001). The compressive stress regime of the northernmost Taiwan appeared to cease during the middle to late Quaternary (Lee and Wang, 1988). The eruption of the Tatun volcanism to the north of the Taipei Basin might reflect the onset of regional extension which was interpreted to be related to the Okinawa trough backarc opening and/or lateral extraction in the corner of plate convergence (Lee and Wang, 1988; Lu et al., 1995; Hu et al., 2002). Subsidence along western margin of the Taipei Basin is interpreted to result from the repeated normal faulting on the Shanchiao Fault as tectonic inversion on the Hsinchuang thrust fault (Chiu, 1968; Hsieh et al., 1992). It turned the Taipei area from rugged mountains into a sediment-receiving basin. The accumulation of fluvial and lacustrine sediments was estimated to be started at about $0.4 \mathrm{Ma}$ (Wei et al., 1998; Teng et al., 2001). Since then the Taipei Basin has kept expanding due to continual asymmetric subsidence along the Shanchiao fault in the western edge of the basin (Wang-Lee et al., 1978). Under the combining influences 
of sea level fluctuations, volcanic activities, drainage system changes, and tectonic processes, the basin was filled with various types of sediments, including alluvial, lacustrine, marine and pyroclastic deposits, as mentioned above.

As a consequence, the Shanchiao Fault, which separates the Linkou Tableland from the Taipei Basin, is considered the major active structure responsible for accommodating the extension across the Taipei region and thus for the formation of the half-graben Taipei Basin (Teng et al., 2001). Shallow seismic reflections across the Shanchiao Fault imaged an offset of Holocene sediments at shallow tens of meters depth (Wang and Sun, 1999). GPS surveys of the Taipei area showed extension with a rate of $0.08 \pm 0.02 \mu$ strain $/ \mathrm{yr}$ in the direction of SEE-NWW across the fault (Yu et al., 1999a). Huang et al. (2007) correlated stratigraphy of three sets of boreholes across the Shanchiao Fault, and identified three paleoseismic events within the Holocene time (8400-8600, 9000-9300, and 11,100 years b.p.). Geomorphology analysis also exhibits series of scarps closely related to the development of the Shanchiao Fault (Chen et al., 2006). Thus the Shanchiao Fault is considered active (as stated in reports of Central Geological Survey, Chang et al., 1998; Lin et al., 2000).

\subsection{Hydrogeologic framework and utilization of groundwater}

Four major aquifers, which generally correspond to the stratigraphic formations, have been defined in the late-Quaternary sediments of the Taipei Basin (Fig. 3b; $\mathrm{Wu}, 1987$ ). The topmost free aquifer (Aquifer 0), which extends from ground surface to depth around $50 \mathrm{~m}$ (except in the western edge of the basin being deeper to about $120 \mathrm{~m}$ in maximum), is composed of interbedded clay, sand and pebbles. Aquifer 0 is thus considered to correspond to the Sungshan formation. The confined Aquifer 1 sits at depth between 50 to around $100 \mathrm{~m}$ (again except in the western edge of basin, about 115$140 \mathrm{~m}$ ) in the conglomerate layer covered by laterite. This conglomerate layer is interpreted to correspond to the Jingmei formation, with hydraulic diffusivity around 0.12 to $0.18 \mathrm{~m}^{2} / \mathrm{s}$ and storage coefficient ranging from 0.001 to 0.004 (Chia et al., 1999). The lower aquifers (Aquifers 2 and 3 ) are present approximately 100 to $130 \mathrm{~m}$ and 140 to $160 \mathrm{~m}$ underground (depths for the central portion of the basin), as two layers of conglomerates within the Wuku and Banchiao formations, respectively (Fig. 3b). Among them Aquifer 1 appeared to be the major groundwater source of the pumping wells in the Taipei Basin. The groundwater of the lower three aquifers comes mainly from two of the major rivers in the Taipei Basin, the Xindian River and the Dahan River (Fig. 3a). On the other hand, rainfall is the major water source for Aquifer 0 (Chia et al., 1999).

First massive utilization of groundwater source in the Taipei Basin (primarily Aquifer 1) was initiated by an English engineer W. K. Bardon in 1895. Under his advisory the government set up 150 wells (Wu, 1987). Since then the number of wells was rapidly increasing and the groundwater resource drained twice in 1906 and 1960 to early 1970s. The second event was accompanied by severe land subsidence. Piezometric head of Aquifer 1 decreased more than $40 \mathrm{~m}$ and reached the lowest point around 1975 (Wu, 1987; Chia et al., 1999; Fig. 3c). The basin-wide subsidence resulted from overpumping was particularly concentrated in the central portion of the Taipei Basin where maximum land subsidence exceeded $2 \mathrm{~m}$ (Fig. 3a), corresponding to the site of major pumping at that time. Severe restriction taken by the government on groundwater pumping in the early 1970s had successfully stopped the fast decline of groundwater table which immediately began to rise as the piezometric head having gradually recovered 30$40 \mathrm{~m}$ in 30 years (Chia et al., 1999; Cho, 2006; Fig. 3c). Water resource of the Taipei metropolitan since the 1970s has been supplied by surface water mainly from two reservoirs in upstream Dahan and Xindian Rivers.

\section{Analyses and results}

\subsection{Description of data analyses}

For the purpose of monitoring the land subsidence due to groundwater pumping, several levelling routes were established by government authorities since 1948 in the Taipei Basin. More than 406 benchmarks were constructed in different periods of the levelling (Fig. 4). Most of the benchmarks were installed on concrete foundation or rock basement. In this study, we analysed the levelling data from 1975 to 2003, in order to decipher effects of post-pumping. Only benchmarks with repeated measurements were taken into account. The observed elevations from these surveys were orthometrically corrected. The more recent data (since 1989) were additionally corrected for temperature variations for rod and instrumental biases. The levelling was deployed conventionally by closing a series of double-run sections. These data sets called TWVD2001 (TaiWan Vertical Datum, the reference of absolute elevation of benchmarks, calculated from the tide data of Keelung tide station) are stored in archive centre of the Ministry of the Interior and Land Subsidence 


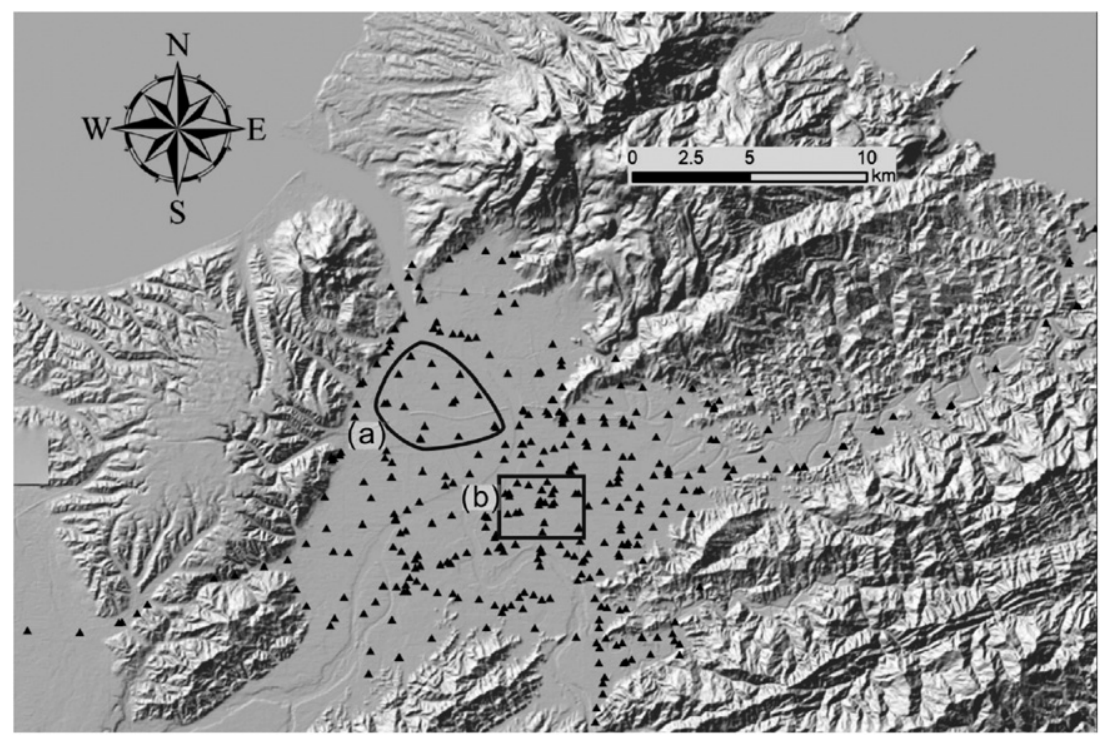

Fig. 4. Distribution of the 406 benchmarks of levelling routes analysed in this study. Benchmarks in groups (a) and (b) are used to represent the average movements in western Taipei Basin and Central Taipei, respectively.

Prevention and Reclamation Corp of National Chengkung University. The survey adopted the standard procedures of the first order high precision levelling, which is of a standard error of about $2 \sqrt{ } D \mathrm{~mm}$, where $D$ is the distance of measurement (unit of $\mathrm{km}$ ). As a result, the uncertainties of the elevations for each benchmark during surveys are usually within $1-3 \mathrm{~mm}$.

For the sake of discontinuity of measurements, we divided the data into 7 periods from 1975 to 2003 (1975-1980, 1980-1985, 1985-1989, 1989-1994, 1994-1996, 1996-2000, and 2000-2003). For each period, the elevation changes of the benchmarks are transferred to elevation change rates, in order for comparison. Based on the rates of elevation change for each benchmark, we then construct contour map of land change for each period (1975-1989 for Fig. 5 and 1989-2003 for Fig. 6), adopting the commonly used extrapolation technique of kriging (Oliver and Webster, 1990). For each period, the contours were derived from data of more than 76 benchmarks. Note that ground level fluctuation shown outside the basin plain is mostly a result of extrapolation which may contain large errors and should not be taken into account.

\subsection{Results of post-pumping land elevation change}

Several interesting and important characteristics of the land surface level change (subsidence and uplift) in the Taipei Basin during the post-pumping time can be inferred from the contour maps. First, the whole basin still subsided after the stop of groundwater pumping, but with a decreasing trend from $40-70 \mathrm{~mm} / \mathrm{yr}$ to $0-30 \mathrm{~mm} / \mathrm{yr}$, during 1975 to 1989, denoted here as Phase 1 (Fig. 5). Second, a large part of the land became to uplift since 1989, denoted as Phase 2 (Fig. 6). However, the surface elevation change was far from homogeneous. For instance, enhanced and persistent subsidence occurred in north-western margin of the basin near Guandu (for the place names mentioned, please refer to Fig. 2b) throughout the entire time span (1975-2003), and concentrated subsidence in western margin of the basin (Wuku, Shulin) and north-eastern basin (Dazhi-Sungshan) was also very persistent before 1996. Other locus of subsidence (e.g., Banchiao, Zhonghe, Jingmei) as well as irregular and short-lived subsidence or uplift were also observed.

A period-by-period account of land elevation change in the Taipei Basin is presented as followed. Basin-wide decreasing subsidence characterized all three periods in Phase 1. During 1975-1980 (Fig. 5a; 94 benchmark), subsidence was dominant and was mostly concentrated in the northwestern (Guandu, exceeded $60 \mathrm{~mm} / \mathrm{yr}$; and Wuku, maximum $75 \mathrm{~mm} / \mathrm{yr}$ ) and northeastern portions (Dazhi, nearly 70 mm/yr). In 1980-1985 (Fig. 5b; 76 benchmark), significant subsidence continuously occurred along the western margin of the basin (Guandu, reached $12 \mathrm{~mm} / \mathrm{yr}$; Wuku, over $10 \mathrm{~mm} / \mathrm{yr}$ ) and in the northeastern corner (Dazhi, more than $20 \mathrm{~mm} / \mathrm{yr}$ ), however, with smaller rates compared to the previous period. For 19851989 (Fig. 5c; 157 benchmark), a large part of areas in the basin were continuous to subside (in particular, the western margin), but some small areas began to show 


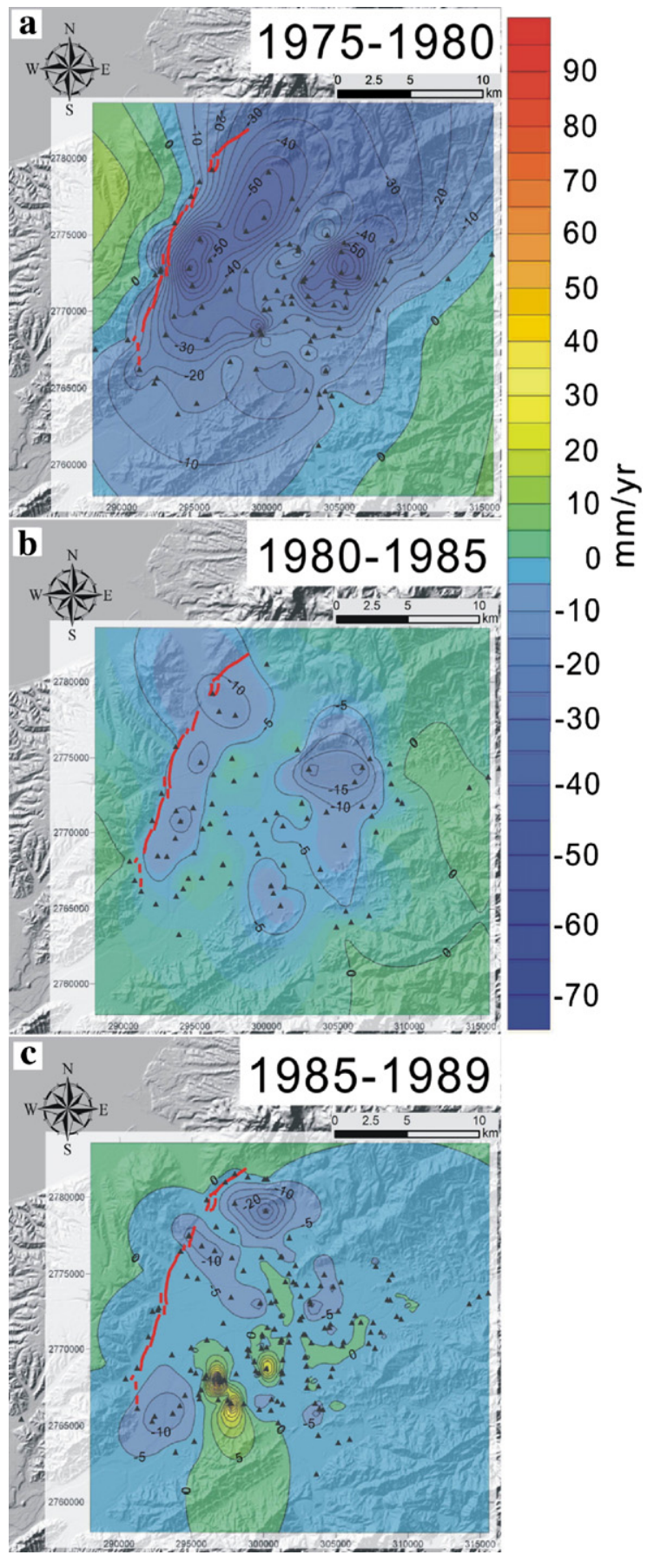

Fig. 5. Contour maps of observed land surface elevation change in Phase 1 (1975-1989) of post-pumping period. (a) 1975-1980. (b) 1980-1985. (c) 1985-1989. Negative rate values indicate subsidence, and vice versa. Contour interval is $5 \mathrm{~mm} / \mathrm{yr}$. Coordinates shown are of TWD 67 Transverse Mercator system. The whole basin revealed a general subsidence from 1975-1985, with some localized effects. See detailed discussion in text. slight uplifting, especially in the central and southern parts, although some of the benchmark records showing extremely sharp uplift might be anomalies. In general, the subsidence rate continued to decrease, comparing to the two previous periods; nonetheless, localized subsidence was still persistent along the western margin of the basin (Guandu, attained $30 \mathrm{~mm} / \mathrm{yr}$; northern Wuku, > $10 \mathrm{~mm} / \mathrm{yr}$; Shulin, $10 \mathrm{~mm} / \mathrm{yr}$ ) and other patches in the basin (south Dazhi, maximum $15 \mathrm{~mm} / \mathrm{yr}$; and Jingmei, around $5 \mathrm{~mm} /$ yr).

Starting from about 1989 (Phase 2), uplift began to appear significantly in the Taipei Basin and declined in magnitude in the later half of this Phase. During 1989 to 1994 (Fig. 6a; 111 benchmark), we observed that the surface subsidence almost ceased and a large portion of the Taipei Basin began to slight uplift, especially in the centre of the basin (central Taipei, 10 to $15 \mathrm{~mm} / \mathrm{yr}$; Banchiao, 10 to $15 \mathrm{~mm} / \mathrm{yr})$. Nevertheless, slight subsidence still persisted in western margin of the basin (e.g., 0 to $5 \mathrm{~mm} / \mathrm{yr}$ in Guandu and Wuku). In 1994-1996 (Fig. 6b; 146 benchmark), slight subsidence continuously occurred and was localized in western side of the basin (Guandu, as high as $14 \mathrm{~mm} / \mathrm{yr}$; Wuku, maximum $10 \mathrm{~mm} / \mathrm{yr}$; and Shulin to Banchiao, up to $6 \mathrm{~mm} / \mathrm{yr}$ ), and in southern Taipei (Zhonghe, reached $10 \mathrm{~mm} / \mathrm{yr}$ ). On the other hand, uplift seemed to dominate the eastern half of the basin, but with a lesser magnitude. In 1996-2000 (Fig. 6c; 103 benchmark), the whole Taipei Basin was generally experiencing mild uplift, except for north-western margin of the basin (Guandu-Wuku, subsidence with a possible bull-eye reaching maximum over $20 \mathrm{~mm} / \mathrm{yr}$ ), and other local areas (Dazhi, Zhonghe, and Jingmei). During the most recent period, 2000-2003 (Fig. 6d; 94 benchmark), slight uplift prevailed in the Taipei Basin $(0-5 \mathrm{~mm} / \mathrm{yr})$ with subsidence in north-western basin (Guandu, Wuku, 0 to $5 \mathrm{~mm} / \mathrm{yr}$ ), and other local areas along the southern and eastern edge of the basin (Sungshan, Zhonghe and Jingmei).

In summary, the subsidence rate for the Taipei Basin as a whole generally decreased from 1975 to 1989 (Phase 1), and then the elevation change of the basin gradually switched to slight uplift since about 1989 during Phase 2 (Fig. 7). The waning subsidence during the 1975-1989 of Phase 1 is interpreted to be mainly ascribed to the compaction of the water-depleted aquifers, resulting from the residual effect of the rapidly declined piezometric head due to over-pumping of groundwater. While massive pumping was ceased, recharge of groundwater from two major rivers (Xindian and Dahan Rivers) to the aquifers has raised the water table for more than $30 \mathrm{~m}$ from the 1970s to 2003 


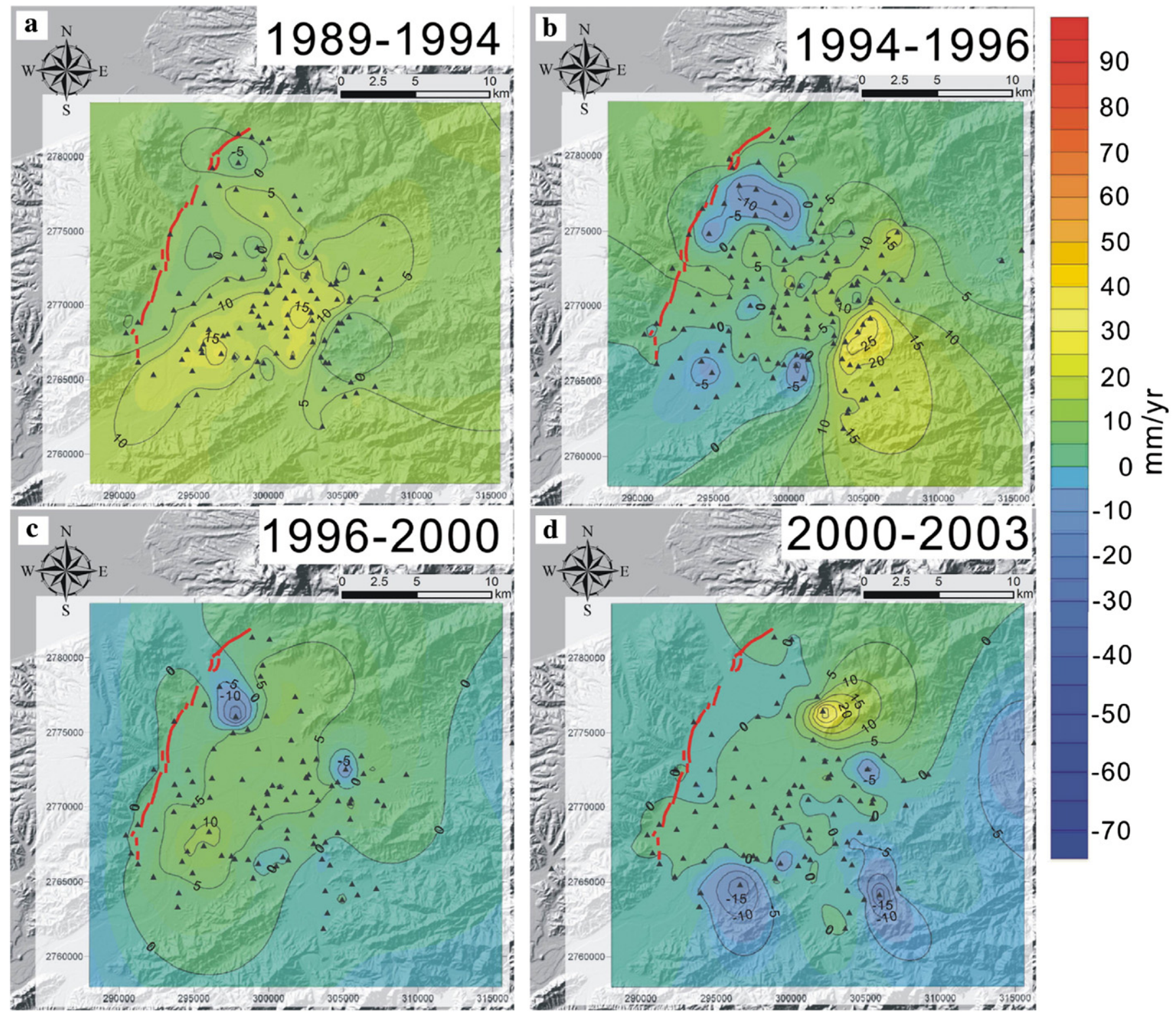
The basin showed a general uplift from 1989 to 2003; however, local subsidence occurred at several places. See details in text. 
(Fig. 3c). We anticipate that the recovery of the groundwater level would produce an elastic rebound for the aquifers, thus caused basin uplift since 1989 in Phase 2. However, the concentrated and rather persistent subsidence and the reduced uplift occurred along the western margin and northern part of the Taipei Basin, compared to the central part of the basin, suggesting under impacts of other factors.

\section{Mechanisms of land elevation changes during post-pumping}

The land elevation change of the Taipei Basin could be a product of complexly interfering natural and artificial processes. The heterogeneous pattern of land vertical changes in the Taipei Basin certainly reflects the spatial and temporal context of different agents. In the spatial domain, these agents, according to where the processes take place, can be described and classified by their operation depth. Here we propose main mechanisms to explain the land elevation changes in the Taipei Basin, attributing effects of land elevation change of the Taipei

\section{a Wuku area (Western Taipei)}

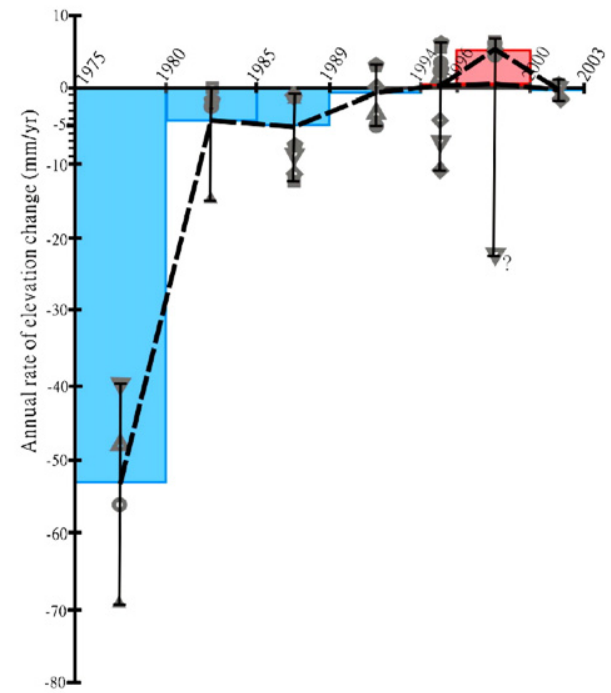

\begin{tabular}{|c|c|c|c|c|c|c|}
\hline \multicolumn{7}{|c|}{ Benchmarks } \\
\hline$\Delta \quad W r 7$ & $\Delta$ & Wr 27 & 0 & Wr 28 & & Wr 43 \\
\hline - Wr 44 & & Wr 45 & & Wr 46 & $\bullet$ & Wr 48 \\
\hline - Wr 50 & & Wr 51 & & Wr 75 & $\boldsymbol{\nabla}$ & Bank 3 \\
\hline
\end{tabular}

Basin to three major components: (1) surface soil compaction (the shallow component), (2) deformation of aquifers, including compaction and elastic rebound due to groundwater effect (the intermediate component), and (3) tectonic load (the deep and crustal-scale component).

\subsection{Near surface soil compaction (the shallow component)}

Local enhanced subsidence can be observed in several areas within the Taipei Basin in many periods we analysed. Subsidence caused by construction (loads of new buildings) cannot be omitted, but such phenomenon might be extremely localized and short-lived. Otherwise, subsidence in several places, such as Dazhi, Sungshan, Jingmei, Banchiao and Shulin, occurred throughout many periods although not always present (Figs. 5 and 6). Since their close proximity to the three major river channels in the Taipei Basin (i.e., Keelung, Dahan and Xindian Rivers), we intend to interpret that a large part of subsidence in these areas to be contributed by compaction of recent flood or overbank deposits (especially mud). Effect of in situ sediment compaction,

\section{b Central Taipei}

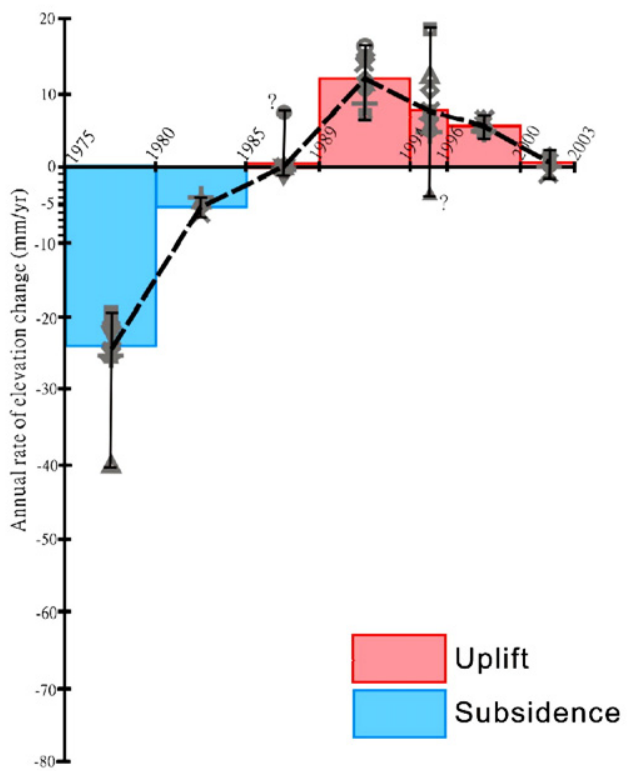

\begin{tabular}{|c|c|c|c|}
\hline \multicolumn{2}{|c|}{ Benchmarks } & $\times$ Lc007 & + Lc008 \\
\hline$\Delta 9535$ & $\Delta 9536$ & $\diamond$ Bdng 12 & $\bullet$ Bdng 22 \\
\hline 口 Bdng 27 & $\square$ Bm No8 & $\diamond$ BM No10 & $\diamond$ CW No5 \\
\hline$\circ$ CW No11 & $\bullet$ Bank 1 & $\nabla$ Kan 39 & $\nabla$ Bm 0 \\
\hline
\end{tabular}

Fig. 7. Evolution of ground elevation change rate in post-pumping period from 1975 to 2003. (a) Western Taipei as the Wuku area. (b) Central Taipei. Distribution of the benchmarks used for calculation is shown on Fig. 4. 
Table 1

The in situ compaction in clayey layers of top $50 \mathrm{~m}$ basin sediments recorded by Lin et al. (1999)

\begin{tabular}{llcl}
\hline Well & $\begin{array}{l}\text { Presence of } \\
\text { clayey } \\
\text { layers } \\
\text { (meters in } \\
\text { depth) }\end{array}$ & $\begin{array}{l}\text { Cumulated } \\
\text { compaction } \\
(\mathrm{mm})\end{array}$ & $\begin{array}{l}\text { Calculated annual } \\
\text { compaction rate } \\
\text { (mm/yr per meter of } \\
\text { clayey layers) }\end{array}$ \\
\hline Wuku (Industrial & $\sim 27-35$ & $4(14-10)$ & 0.1429 \\
Park) & $\sim 42-48$ & $4(6-2)$ & 0.1905 \\
$\begin{array}{c}\text { Banchiao (Veterans } \\
\text { Affair Office) }\end{array}$ & $\sim 10-20$ & $10(18-8)$ & 0.2857 \\
\hline
\end{tabular}

The averaged annual rate of compaction in 1-meter-thick clayey layers is deduced.

often referred as natural subsidence (Waltham, 2002), therefore must be evaluated in order to further distinguish the role and intensity of natural and artificial factors played on the observed ground level change.

According to a recent in situ study in the Taipei Basin conducted by Lin et al. (1999), compaction of the loose sediments occurred mainly in the clayey layers of the uppermost $50 \mathrm{~m}$ Holocene deposits (generally corresponding to the Sungshan Formation) in three monitored wells in the western part of the basin at Wuku and Banchiao, in a time span of three and a half years from March, 1994 to September, 1997. For older sediments underneath, the compaction and consolidation were observed to be rather slow and was ignorable regardless of the types of the deposits. Based on their results, we estimated the averaged annual rate of compaction for 1meter-thick clayey layers to be ranging from 0.14 to $0.28 \mathrm{~mm} / \mathrm{yr}$ (Table 1) by dividing the cumulative compaction of the clay sections in the monitored wells by the monitoring interval of three and half years. Meanwhile we reconstructed an isopach map for clay thickness within the topmost deposits of the Sungshan Formation in the basin (Fig. 8a) based on 350 borehole records from Central Geological Survey (open source, available on http://210.69.81.69/geo/frame/gsb88.cfm). The proxy of present variation of shallow soil compaction rate in the Taipei Basin can be obtained by multiplying the deduced average annual compaction rate for 1-meter-thick clay (i.e., $0.2 \pm 0.07 \mathrm{~mm} / \mathrm{yr}$ ) with the shallow clay thickness isopach. We estimate contemporary shallow soil compaction to contribute $1-8 \mathrm{~mm} / \mathrm{yr}$ of subsidence in the basin with most land ranging 2 to $5 \mathrm{~mm} / \mathrm{yr}$ (Fig. $8 \mathrm{~b}$ ).

Natural subsidence rates of surface soil documented elsewhere in similar flood plain and deltaic environments fall in the same order of magnitude (Jelgersma, 1996), such as Ravenna (4-6 mm/yr, Teatini et al., 2005), Romagna (0-5 mm/yr, Gambolati et al., 1999), Venice (0.5-1.3 mm/yr, Gatto and Carbognin, 1981), and Po River Delta (3-5 mm/yr, Gambolati and Teatini, 1998) in Italy and coastal Louisiana, USA (shallow component $1.5-2.5 \mathrm{~mm} / \mathrm{yr}$, Dokka, 2006). In addition, the modelling results of Meckel et al. (2006) based on Holocene

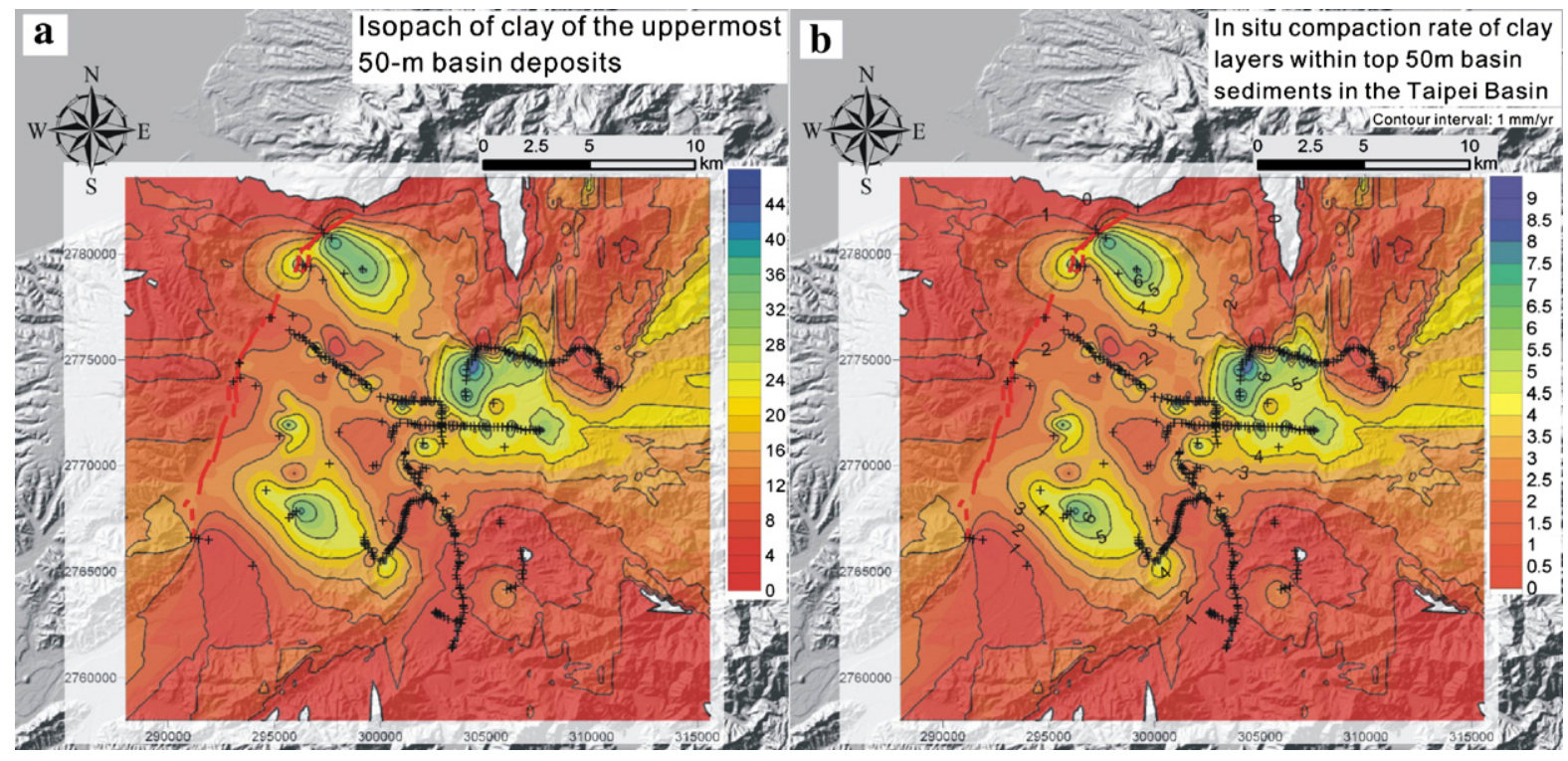

Fig. 8. (a) Isopach of the Holocene clayish sediments (topmost 50-m deposits) in Taipei Basin, constructed from 350 borehole records from Central Geological Survey (borehole sites marked in cross). (b) Estimated compaction rate of clayey layers within the Holocene deposits (soil compaction). See text for reference. 
stratigraphy of lower Mississippi River Delta in southern Louisiana, which closely resembles the compacting shallow sediments of the Sungshan formation in the Taipei Basin, is applied to evaluate our proxy. Taking the surface soil in the Taipei Basin (50-meter-thick and deposited within the Holocene) into their cumulative distribution functions of compaction rate model, the 90th percentile compaction rate (Fig. 2 of Meckel et al., 2006) ranges from 1.5 to $4 \mathrm{~mm} / \mathrm{yr}$. This suggests that our estimate is reasonable and not likely to underestimate present soil compaction.

Comparison between the contour maps of the observed elevation change (Figs. 5 and 6) and the estimated shallow soil compaction (Fig. 8b) shows that concentrated subsidence are indeed in a close relation with thicker soil/clay layers, especially along the main river courses (Fig. 3a). For example, ultra thick clay with resultant peak soil compaction is likely the main source of continuous subsidence in the marshy Guandu area along the Danshui River in the north-western corner of the basin. However, the Wuku area in western Taipei, on the contrary, is not subject to high soil compaction. As a consequence, persistent subsidence in the western margin of the Taipei Basin (Guandu, Wuku, and sometimes extending to Shulin) cannot be attributed totally to natural compaction especially during Phase 2, and requires other explanations to decipher its origin.

\subsection{Tectonic load (the deep and crust-scale component)}

Tectonic subsidence from activities of the Shanchiao Fault is thought to affect ground surface elevation change since present extensional deformation across the fault was documented (Yu et al., 1999a). It's expected to be most pronounced in the near-fault hanging-wall region, that is, the western margin of the basin, where the basin basement is dramatically deepened and reaches maximum depth. The long-term averaged tectonic subsidence rate in western Taipei Basin thus can be estimated by stratigraphic offset across the fault. The onset of basin sediment deposition was estimated to be around 0.4 Ma when basin basement was lowered to near sea level (Chen et al., 1995; Wei et al., 1998; Teng et al., 2001) and since then approximately $700 \mathrm{~m}$ of basin sediments were accumulated. Dividing the total thickness of late-Quaternary basin deposits $(700 \mathrm{~m})$ by the time span of sedimentation $(0.4 \mathrm{Myr})$ we obtain the late-Quaternary averaged tectonic subsidence rate to be $1.75 \mathrm{~mm} / \mathrm{yr}$ since $0.4 \mathrm{Ma}$. Note that it may contain contributions from co-seismic slips (Huang et al., 2007), thus representing the upper limit of value for interseismic tectonic subsidence rate. In the central part of the basin tectonic subsidence may attain half of the rate in western Taipei, approximately $0.88 \mathrm{~mm} / \mathrm{yr}$. We consider the tectonic subsidence rates to be constant over the investigated time intervals since no major earthquakes were recorded in shallow crust of the Taipei area during 1975 to 2003 . More accurate assessment of the ongoing tectonic subsidence could be derived from levelling of benchmarks attached to deep boreholes (e.g. Dokka, 2006) and is in urgent need for earthquake hazard research and mitigation in the Taipei metropolis.

\subsection{Deformation of aquifers (the intermediate component)}

In the hydro-mechanical coupling scheme as illustrated by Waltham (2002), abstracting groundwater would reduce pore-water pressure in aquifers, usually as sand or conglomerate beds, which behave in a seemingly elastic manner (Karig and Hou, 1992). However, this would be followed by reduced porewater pressure in usually intercalated clay and aquitard materials in order to regain hydraulic equilibrium. Clay compaction is largely an irreversible one-way process, and is the major source for severe pumping-induced land subsidence (Terzaghi, 1925; Holzer, 1984; Phienwej et al., 2006). When groundwater is recharged into the starved aquifers to recover the pore pressure, expansion of aquifer sand and gravel layers occurs and contributes to uplift of ground surface as elastic rebound (Waltham, 2002). In detail of this hydro-mechanical coupling, during piezometric head rise, the recharged sections of the aquifer will release the formerly imposed compressive strain to show dilatation, producing elastic rebound. On the other hand, the starved sections of aquifer and aquitard will continue to show compression as the result of time-dependent consolidation behaviour caused by past piezometric drawdown, until groundwater table has risen to remove deficits of pore pressure in these sections. Ground level change reflected on groundwater recovery is the competition between subsidence from starved aquifer (plus aquitard) section and uplift from the recharged aquifer section. The evolution generally follows the pattern of curve B in Fig. 1. Similar mechanism was also invoked to explain land level fluctuation in Las Vegas controlled by seasonal water table variations (Amelung et al., 1999).

According to well monitor records in the Taipei Basin (Fig. 3c), groundwater table started to rise as soon as pumping ceased in 1975. Compaction of Aquifer 1 during massive groundwater extraction would arrest gradually, following the recharge of groundwater in the aquifer. Near the end of Phase 1 as piezometric head was largely recovered, deformation of aquifer would become 
neutral as that rebound had developed to surpass remaining compaction. The uplift due to elastic rebound of Aquifer 1 was not visible on land surface until 1989 at the beginning of Phase 2 (Fig. 6). We interpret that at this time the amount and rate of elastic rebound outpaced residual aquifer clay compaction and other subsidence effects including the compaction of surface soil and tectonic subsidence of normal faulting. Elastic rebound of recharged aquifer would then gradually decrease in amount and rate since the groundwater level stabilized from mid 1990s. Ground level change pattern of the Taipei Basin after cessation of massive pumping with natural groundwater recharge thus fits well with the scheme of curve B in Fig. 1. The evolution of the postpumping elevation change is characterized by a relatively longer period of waning subsidence (Phase
1: 1975-1989) followed by a shorter period of slight uplift (Phase 2: 1989-2003), due to a combination of decreasing compaction and increasing refill in Aquifer 1. The time lag between the start of piezometric level rise $\left(t_{\text {stop }}\right.$ in Fig. 1) and the first occurrence of the observed uplift of land surface ( $t_{\text {rebound }}$ in Fig. 1) in Taipei Basin is about 15 years, which is believed to be closely related to the recharge rate of Aquifer 1. The contrast on amount between the non-revertible, plastic clay compaction and the elastic rebound of aquifer strata may be a viable explanation to the fact that the recent uplift (since 1989) in the Taipei Basin has a much lesser magnitude than that of the severe subsidence during massive pumping as before the 1970s. Most surface uplift due to rebound was observed in the central to eastern portion of the basin, roughly corresponding to
Simplified log of
the Taipei Basin

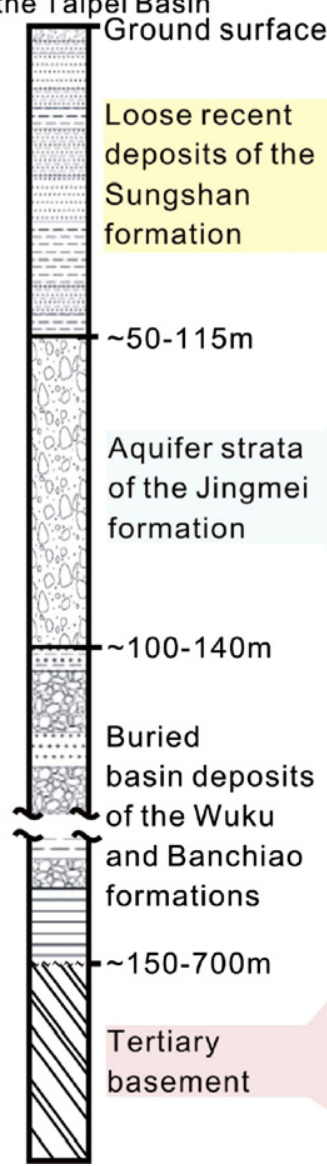

Wuku (Western Taipei)
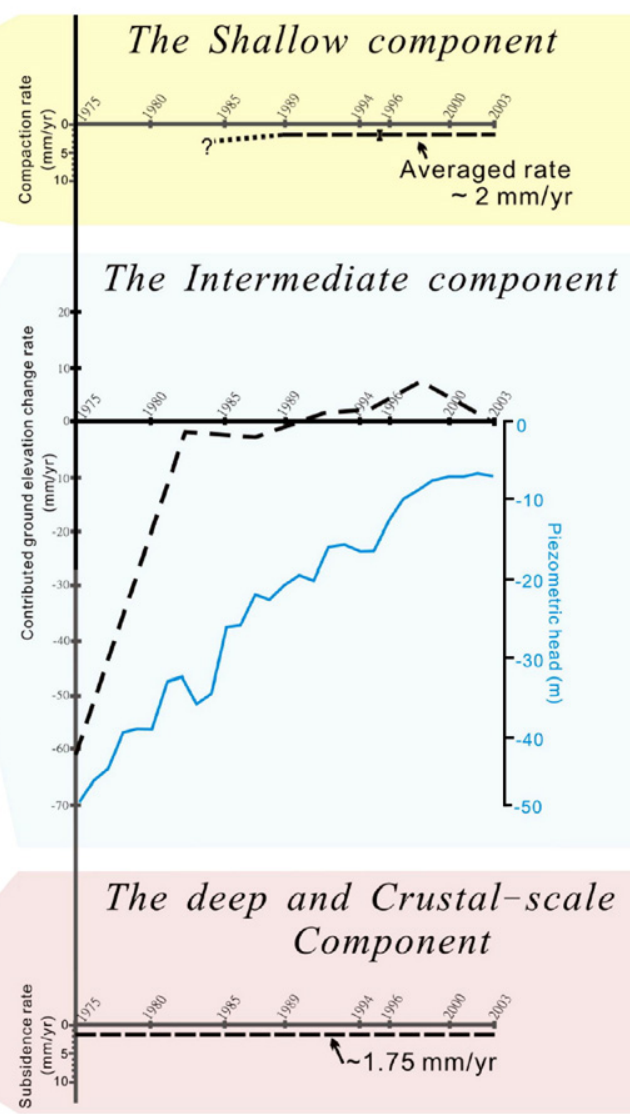

Central Taipei

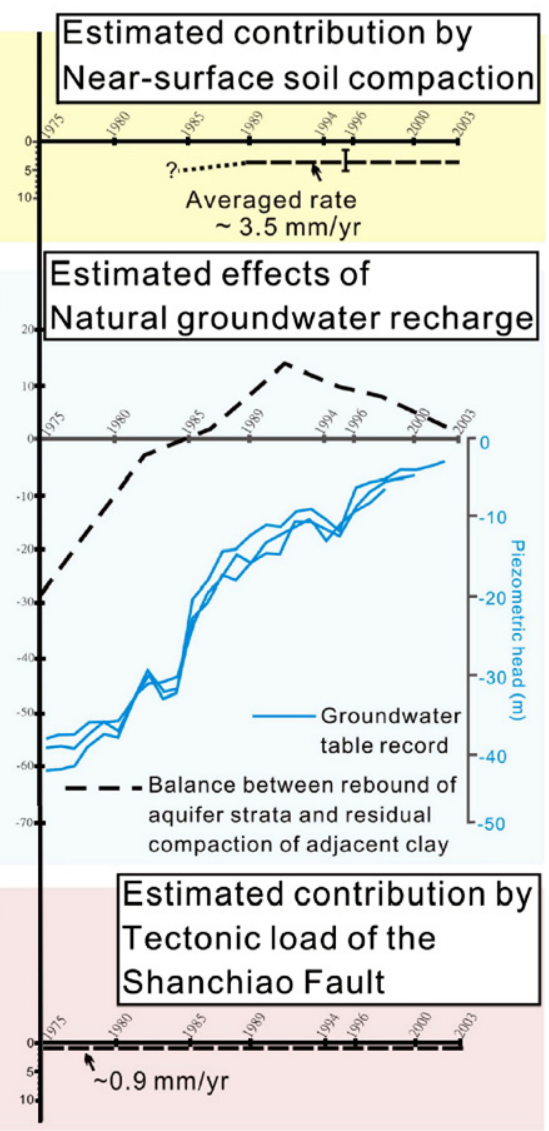

Fig. 9. Mechanisms of three depth-related component responsible for land elevation change in Western Taipei (Wuku) and Central Taipei. The shallow component represents the surfacial soil compaction with the average rates estimated after Lin et al. (1999). The intermediate component represents the aquifer deformation consists of compaction and elastic rebound within Aquifer 1. The deep and crustal-scale component represents asymmetric tectonic subsidence due to the activity of the Shanchiao fault in the western margin of the basin. Calculation of each component is explained in the text. 
area of most intense anthropogenic subsidence during pumping (compare Fig. 6 and Fig. 3a).

Similar phenomenon following cessation of massive groundwater exploitation was documented in Venice, Italy by Gatto and Carbognin (1981) where a land rebound of $2 \mathrm{~cm}, 15 \%$ of subsidence due to groundwater withdraw, occurred about 5 years later than the onset of regional piezometric head recovery from natural recharge. Artificial recharge of a severely depleted hydrocarbon reservoir in Long Beach, California, induced an observed rebound of $33.5 \mathrm{~cm}$ where precedent subsidence due to petroleum production reached $9 \mathrm{~m}$ in maxima (Allen and Mayuga, 1969). Both cases demonstrated that aquifer rebound is generally about one order less in magnitude than the preceding subsidence. This is in good accordance with the situation in the Taipei Basin, whose subsidence is of $2 \mathrm{~m}$ and rebound is of $10-20 \mathrm{~cm}$ in general. Recent studies of geodetic records in regions including Ravenna, Italy (Teatini et al., 2005) and Shanghai, China (Chai et al., 2004) displayed a sharp change on subsidence rates showing a switch from severe to slight subsidence while groundwater utilization was controlled or stopped; however, no uplift due to aquifer rebound was observed in these above regions yet. Differences in groundwater exploitation history, piezometric level evolution, and local hydrogeological properties (e.g. aquifer compressibility, porosity, permeability) are major factors for the discrepancies documented in the localities cited above.
As mentioned above in Section 2.2, most groundwater extraction in the Taipei Basin was from Aquifer 1, which is generally located about 50 to $100 \mathrm{~m}$ underground within the Jingmei Formation. We intend to call the direct resultant effects from post-pumping compaction and rebound of aquifer strata due to natural recharge of groundwater as the "intermediate" component, compared with the compaction of the surface soil above the Aquifer 1 and the possible crust-scale subsidence due to the normal faulting of the Shanchiao Fault. This component is expected to have basin-wide impact since the Aquifer 1 is distributed throughout the entire basin.

\subsection{Synthesis and discussion}

The mechanisms of land elevation change in the Taipei Basin during the past 30-year post-pumping period are summarized in Fig. 9, showing the effect from three major depth-related components in the central and western parts of the basin. Soil compaction (the shallow component) is estimated with averaged rates of $3.5 \mathrm{~mm} / \mathrm{yr}$ and $2 \mathrm{~mm} / \mathrm{yr}$ for Central Taipei and the western margin, respectively (see Fig. 8, Section 4.1.). The tectonic load from the Shanchiao Fault (the deep and crustal-scale component) contributes subsidence of approximately $1.75 \mathrm{~mm} / \mathrm{yr}$ for the western margin of the basin and $0.9 \mathrm{~mm} / \mathrm{yr}$ for Central Taipei (discussed in Section 4.2.). As for aquifer deformation (the intermediate component), due to combination of

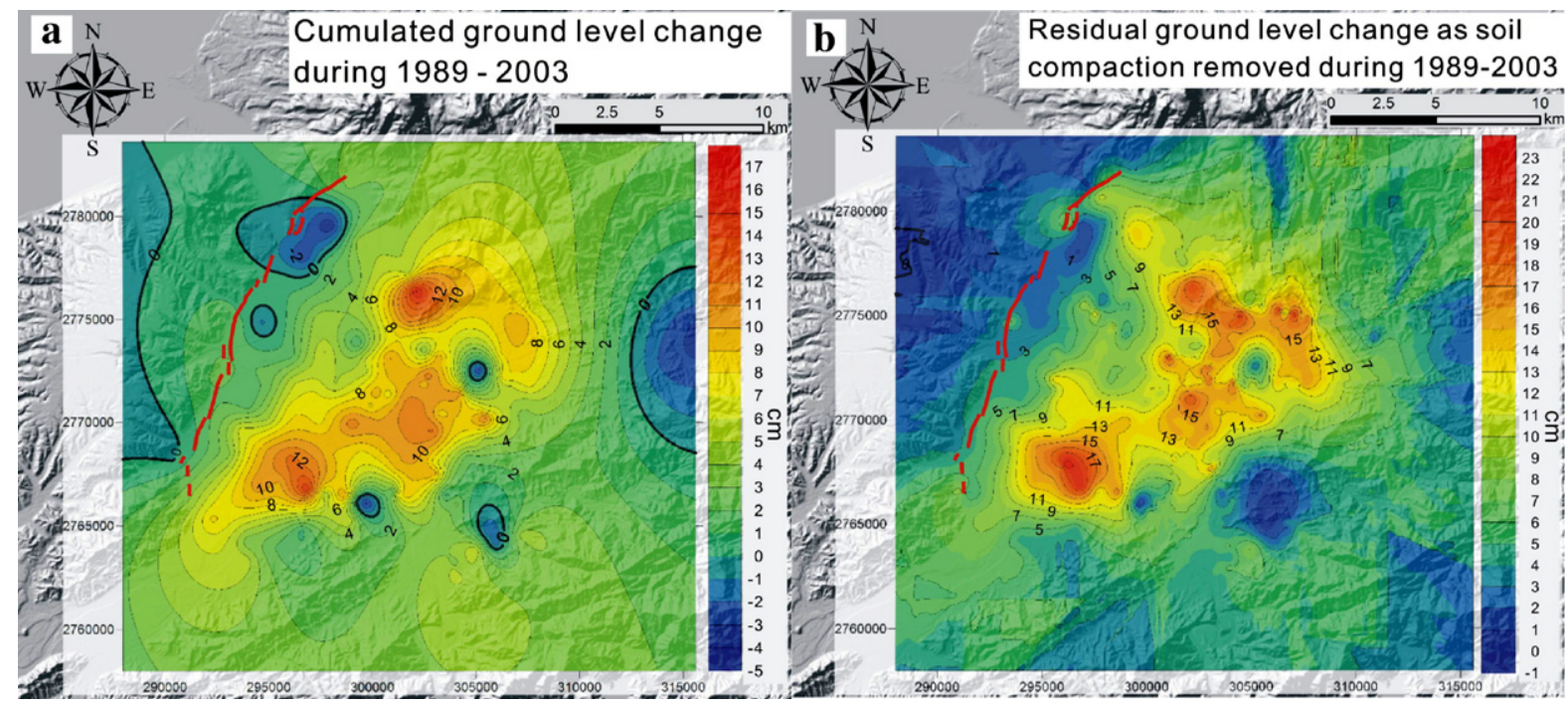

Fig. 10. Ground level changes during Phase 2 of post-pumping period. (a) Cumulated ground elevation change from 1989 to 2003 . (b) Residual ground elevation change from 1989 to 2003 as soil compaction (shallow component) removed. 
compaction and rebound of natural recharge, its deformation rate is estimated by subtracting the soil compaction rate and the tectonic subsidence rate from the land elevation change rate. We thus obtain the evolution of the aquifer deformation rate in western and central Taipei Basin, as the dashed curve in Fig. 9.

As revealed by Fig. 9, among the three major mechanisms, the aquifer deformation appears to be the main driving source of ground elevation changes, that is, subsidence in Phase 1 and uplift in Phase 2. Further- more, the observed prominent land uplift in Phase 2, which is interpreted to be mainly related to the aquifer rebound, was significantly less in western margin than in Central Taipei.

In order to illuminate the actual extent of effects from aquifer deformation (compaction versus rebound) and tectonic load, we sum up the ground level change in the Taipei area during Phase 2 (1989-2003, Fig. 10a) then remove estimate of shallow soil compaction to create the map of residual cumulative ground level change
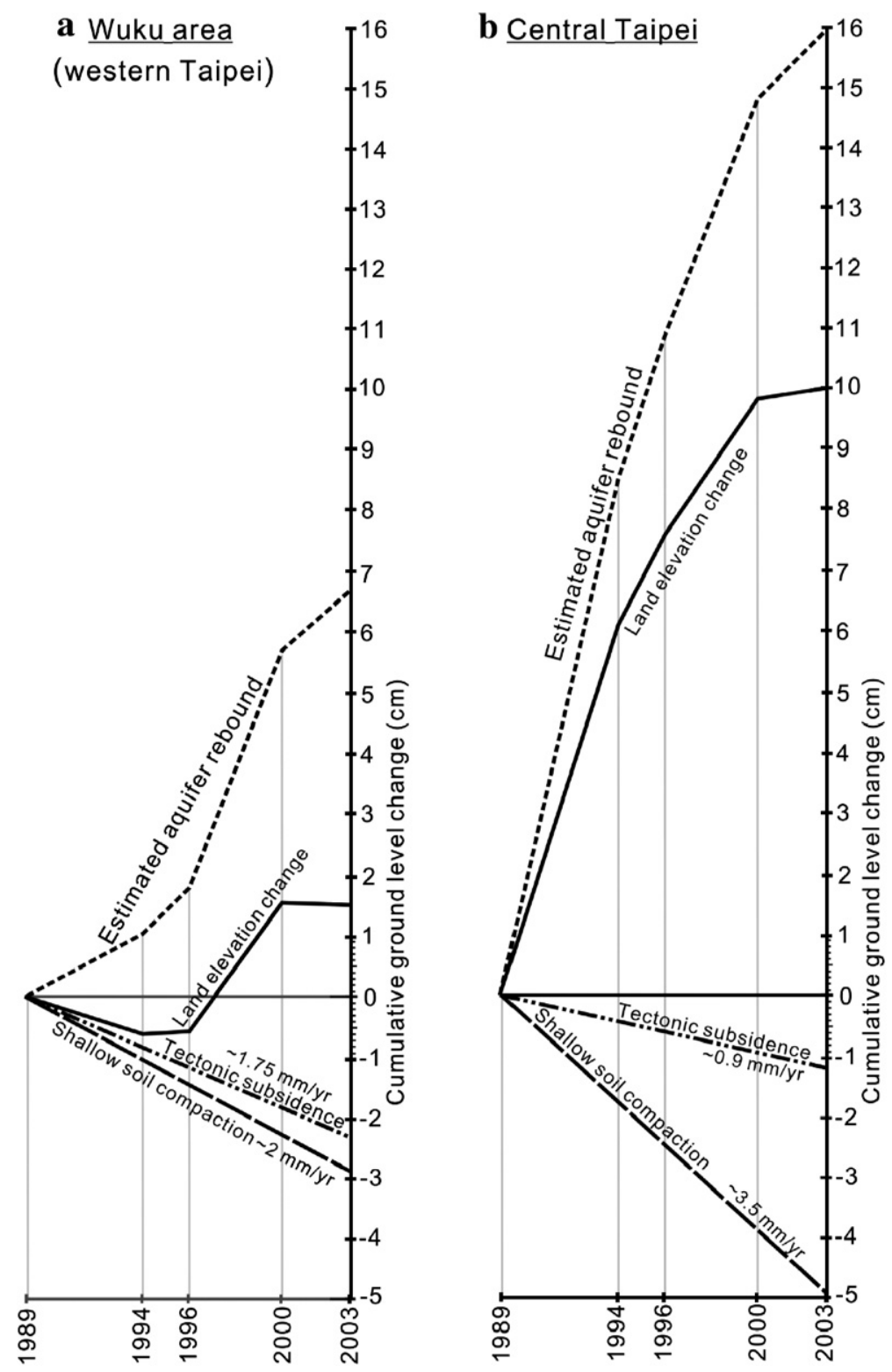

Fig. 11. A schematic model for evaluating aquifer elastic rebound during the Phase 2 of the post-pumping period 1989-2003, in (a) Wuku (Western Taipei) and (b) Central Taipei. 
(Fig. 10b). The major remaining factors affecting land elevation fluctuation during Phase 2 are (1) elastic rebound of recharged Aquifer 1 contributing uplift and (2) tectonic subsidence. Note that the residual compaction of Aquifer 1 had declined to a neglected minimal rate as groundwater table almost fully recovered and stabilized. Most of the Taipei Basin, except the western margin, showed rather homogeneous uplift of 13-18 cm (spatial variation) during 1989-2003 (or 9-13 mm/yr in average), and is interpreted as a manifestation of elastic rebound of Aquifer 1 due to natural recharge. The western part of the basin, in contrast, exhibited less amount of uplift $(1-9 \mathrm{~cm}$, or $0-6 \mathrm{~mm} / \mathrm{yr}$ in average throughout the area) which decreased toward the west and northwest (also exhibited in Fig. 7). The "differential uplift" was partially resulted from variations of elastic rebound of Aquifer 1 possibly related to changes in sedimentary facies (hence the thickness and composition of the aquifer strata) and hydrological parameters. However, the pattern of uplift diminishing toward the Shanchiao Fault also demonstrated a likely effect of tectonic load especially for the near-fault hanging-wall regions including Guandu, Wuku, and Shulin.

A schematic model of mechanisms for the cumulative land elevation changes of Central and Western Taipei areas during Phase 2 of post-pumping from 1989 to 2003 is presented in Fig. 11. For Central Taipei, adapting $3.5 \mathrm{~mm} / \mathrm{yr}$ of shallow soil compaction and $0.9 \mathrm{~mm} / \mathrm{yr}$ of long-term tectonic subsidence, we obtain a total aquifer rebound of $16 \mathrm{~cm}$ in 1989-2003 (Fig. 11b). For the Wuku area of western Taipei in the same manner by adopting averaged shallow soil compaction of $2 \mathrm{~mm} / \mathrm{yr}$ and the long-term tectonic subsidence rate of $1.75 \mathrm{~mm} / \mathrm{yr}$, we come to an estimation of rebound in the region as $6.7 \mathrm{~cm}$ in 1989-2003 (Fig. 11a). The values of total rebound are of reasonable magnitude as the preliminary test given below. Based on injection experiments carried out in Wilmington oilfield, California, Allen and Mayuga (1969) proposed a simplified empirical equation: the amount of rebound $(u)$ is a function of thickness of the recharged aquifer strata $\left(t_{\text {aquifer }}\right)$ :

$u=a \cdot b t_{\text {aquifer }}$

Where $a$ is the ratio of surface uplift to actual amount of aquifer elastic rebound and was given as $0.5, b$ is the expansion factor per aquifer unit and was estimated to be 0.005 per unit. Taking averaged thickness of Aquifer 1 (the Jingmei formation) of $50 \mathrm{~m}$ in Central Taipei into calculation, the aquifer rebound is estimated to be $12.5 \mathrm{~cm}$. For Western Taipei by adapting known minimum thickness of Aquifer 1 in the region as $25 \mathrm{~m}$, amount of the aquifer rebound is estimated to be $6.25 \mathrm{~cm}$. Although minor amount of aquifer rebound may still be in operation after 2003, fair agreement is found between the above estimation and our results (16 $\mathrm{cm}$ versus $12.5 \mathrm{~cm}$ in Central Taipei, and $6.7 \mathrm{~cm}$ versus 6.25 in Western Taipei).

Improvements from these preliminary results and statements will come from more comprehensive study on geotechnical and hydrological properties of the basin deposits to contribute a realistic modelling, and further level monitoring of both ground surface and down-hole benchmarks.

\section{Summary}

Land elevation change during post-pumping in 1975-2003 in the Taipei Basin illuminated by levelling data was documented in details. The post-pumping behaviour is characterized by an interval of waning subsidence followed by one of slight uplift, as Phase 1 and Phase 2, respectively. This behaviour was dominated by aquifer internal deformation in response to piezometric level changes. The aquifer is observed to exhibit substantial elastic rebound in the later stage of groundwater recharge, whose magnitude is about $10 \%$ of that of the former pumping-induced subsidence. This further confirms that land subsidence caused by aquifer/ reservoir overdraft is largely an irreversible process and should be avoided especially in critical areas of flat lowlying topography and flood risk.

Two other major mechanisms also imposed significant effects on basin ground level change. Shallow soil compaction contributed enhanced subsidence especially near river courses and marshy areas. Regional tectonic asymmetric subsidence related to the Shanchiao normal Fault, whose effect is observable from the elevation change data, is interpreted to be the main agent responsible for continued subsidence in the western margin of the basin on the hanging wall near the fault line.

\section{Acknowledgements}

We thank LSPRC (Land Subsidence Prevention and Reclamation Corp) of National Chengkung University for kindly providing levelling data and Central Geological Survey, MOEA for borehole data. We also thank H.-T. Chu, Y.-G. Chen, L. S. Teng, K.-C. Chang, and C. Huang for helpful comments and suggestions. This work is supported by National Science Council of R.O.C. (grant NCS-95-2922-I-002-239). 


\section{References}

Abidin, H.Z., Djaja, R., Darmawan, D., Hadi, S., Akbar, A., Rajiyowiryono, H., Sudibyo, Y., Meilano, I., Kasuma, M.A., Kahar, J., Subarya, C., 2001. Land subsidence of Jakarta (Indonesia) and its geodetic monitoring system. Natural Hazards 23, 365-387.

Allen, D.R., Mayuga, M.N., 1969. The mechanics of compaction and rebound, Wilmington Oil Field, Long Beach, California, U.S.A. Proceedings of the Tokyo Symposium on Land Subsidence 2, 410-423, International Association of Scientific Hydrology and UNESCO, September 1969, Tokyo.

Amelung, F., Galloway, D.L., Bell, J.W., Zebker, H.A., Laczniak, R.J., 1999. Sensing the ups and downs of Las Vegas: InSAR reveals structural control of land subsidence and aquifer-system deformation. Geology 27-6, 483-486.

Cappa, F., Guglielmi, Y., Fenart, P., Merrien-Soukatchoff, V., Thoraval, A., 2005. Hydromechanical interactions in a fractured carbonate reservoir inferred from hydraulic and mechanical measurements. International Journal of Rock Mechanics and Mining Sciences 42, 287-306.

Chai, J.-C., Shen, S.-L., Zhu, H.-H., Zhang, X.-L., 2004. Land subsidence due to groundwater drawdown in Shanghai. Géotechnique 54-2, 143-147.

Chang, H.-C., Lin, C.-W., Chen, M.-M., Lu, S.-T., 1998. An Introduction to the Active Faults of Taiwan, Explanatory Text of the Active Fault Map of Taiwan (in Chinese with English abstract). Special Publication of Central Geological Survey, vol. 10. Central Geological Survey, Ministry Economical Affairs, Taipei, Taiwan, R.O.C. 103 pp.

Chen, C.-H., Lee, C.-Y., Lin, S.-B., 1995. The eruption age of volcanic ashes in the Wuku Well, Taipei Basin: constraints on mineral chemistry and $40 \mathrm{Ar} / 39 \mathrm{Ar}$ dating. Journal of Geological Society of China 38, 371-382.

Chen, C.-T., Lee, J.-C., Hu, J.-C., Chan, Y.-C., Lu, C.-Y., 2006. The active Shanchiao Fault in the Metropolitan Taipei Area, Northern Taiwan: geomorphic and geodetic analyses. Eos Trans. AGU 8752, Fall Meeting Supplement, T33D-0543. Abstract.

Chen, W.-F., Teng, L.S., 1990. Depositional environment of Quaternary deposits of the Linkou Tableland, northwestern Taiwan. Proceedings of the Geological Society of China 33, 39-63.

Chia, Y.-P., Chang, M.-H., Liu, W.-I., Lai, T.-C., 1999. Hydrogeologic characterization of Taipei Basin (in Chinese with English abstract). Central Geological Survey Special Publication 11, 393-406.

Chiu, H.T., 1968. The Hsinchuang Fault in the Taoyuan area, northern Taiwan. Proceedings of Geological Society of China 11, 60-73.

Cho W.-C., 2006. Groundwater level change and elevation fluctuation of the Taipei Basin. Master thesis, National Taiwan University, Taipei, $73 \mathrm{pp}$.

Dokka, R.K., 2006. Modern-day tectonic subsidence in coastal Louisiana. Geology 34, 281-284.

Gambolati, G., Teatini, P., 1998. Natural land subsidence due to compaction of the upper Adriatic Sea Basin. IGEA 11, 29-40.

Gambolati, G., Teatini, P., Tomasi, L., Gonella, M., 1999. Coastline regression of the Romagna region, Italy, due to natural and anthropogenic land subsidence and sea level rise. Water Resources Research 35-1, 163-184.

Gatto, P., Carbognin, L., 1981. The Lagoon of Venice: natural environmental trend and man-induced modification. Hydrological Sciences-Bulletin 26 (4), 379-391.

Ho, C.-S., 1975. An Introduction to the Geology of Taiwan. Ministry of Economic Affairs, Republic of China. 143 pp.
Holzer, T.L., 1984. Ground failure induced by groundwater withdrawal from unconsolidated sediments. Reviews in Engineering Geology 6, 67-105.

Hsieh, C.-H., Chang, Y.-F., Sun, R.-H., 1992. Seismic investigate Hsin-Chuan fault on the west of Taipei Basin (in Chinese with English abstract). Ti-Chih 12 (1), 13-26.

Hu, J.-C., Yu, S.-B., Chu, H.-T., Angelier, J., 2002. Transition tectonics of northern Taiwan induced by convergence and trench retreat. Geological Society of America Special Paper 358, 149-162.

Hu, J.-C., Chu, H.-T., Hou, C.-S., Lai, T.-H., Chen, R.-F., Nien, P.-F., 2006. The contribution to tectonic subsidence by groundwater abstraction in the Pingtung area, southwestern Taiwan as determined by GPS measurements. Quaternary International 147, $62-69$.

Huang, S.-Y., Rubin, C.M., Chen, Y.-G., Liu, H.-C., 2007. Prehistoric earthquakes along the Shanchiao Fault, Taipei Basin, Northern Taiwan. Journal of Asian Earth Sciences. doi:10.1016/j.jseaes. 2006.07.025.

Hwang, J.-M., Wu, C.-M., 1969. Land subsidence problems in Taipei Basin. Proceedings of the Tokyo Symposium on Land Subsidence 1, 21-34, International Association of Scientific Hydrology and UNESCO, September 1969, Tokyo.

Jelgersma, S., 1996. Land subsidence in coastal lowlands. In: Milliman, J.D., Haq, B.U. (Eds.), Sea-Level Rise and Coastal Subsidence, pp. 47-62.

Kao, H., Shen, S.J., Ma, K.-F., 1998. Transition from oblique subduction to collision: earthquakes in the southernmost Ryukyu arc-Taiwan region. Journal of Geophysical Research 103, 7211-7229.

Karig, D.E., Hou, G., 1992. High-stress consolidation experiments and their geologic implications. Journal of Geophysical Research 97 (B1), 289-300.

Lee, C.-T., Wang, Y., 1988. Quaternary stress changes in northern Taiwan and their tectonic implication. Proceedings of the Geological Society of China 31 (1), 154-168.

Lin, C.-W., Chang, H.-C., Lu, S.-T., Shih, T.-S., Huang, W.-J., 2000. An introduction to the active faults of Taiwan, Explanatory Text of the Active Fault Map of Taiwan (in Chinese with English abstract), 2nd ed. Special Publication of Central Geological Survey, vol. 13. Central Geological Survey, Ministry Economical Affairs, Taipei, Taiwan, R.O.C. 122 pp.

Lin, M.-L., Huang, T.-H., Hung, J.-J., Chi, C.-C., 1999. A study on in situ measurement of ground subsidence of Taipei Basin (in Chinese with English abstract). Central Geological Survey Special Publication 11, 317-344.

Lu, C.-Y., Angelier, J., Chu, H.-T., Lee, J.-C., 1995. Contractional, transcurrent, rotational and extensional tectonics: examples from Northern Taiwan. Tectonophysics 246, 129-146.

Meckel, T.A., ten Brink, U.S., Williams, S.J., 2006. Current subsidence rates due to compaction of Holocene sediments in southern Louisiana. Geophysical Research Letters 33, L11403. doi:10.1029/2006GL026300.

Oliver, M.A., Webster, R., 1990. Kriging: a method of interpolation for geographical information system. International Journal of Geographical Information Systems 4 (3), 313-332.

Phien-wej, N., Giao, P.H., Nutalaya, P., 2006. Land subsidence in Bangkok, Thailand. Engineering Geology 82, 187-201.

Shyu, J.B.H., Sieh, K., Chen, Y.-G., Liu, C.-S., 2005. Neotectonic architecture of Taiwan and its implications for future large earthquakes. Journal of Geophysical Research 110, B08402. doi:10.1029/2004JB003251.

Suppe, J., 1981. Mechanics of mountain building and metamorphism in Taiwan. Memoir of the Geological Society of China 4, 67-89. 
Teatini, P., Ferronato, M., Gambolati, G., Bertoni, W., Gonella, M., 2005. A century of land subsidence in Ravenna, Italy. Environmental Geology 47, 831-846.

Terzaghi, K.T., 1925. Erdbaumechanik auf Bodenphysikalischer Grundlage: Wien, Deuticke. 399 pp.

Teng, L.S., 1990. Late Cenozoic arc-continent collision in Taiwan. Tectonophysics 183, 57-76.

Teng, L.S., Yuan, P.B., Chen, P.-Y., Peng, C.-H., Lai, T.-C., Fei, L.-Y., Liu, H.-C., 1999. Lithostratigraphy of Taipei Basin deposits (in Chinese with English abstract). Central Geological Survey Special Publication 11, 41-66.

Teng, L.S., Lee, C.-T., Tsai, Y.-B., Hsiao, L.-Y., 2000. Slab breakoff as a mechanism for flipping of subduction polarity in Taiwan. Geology 28, 155-158.

Teng, L.S., Lee, C.-T., Peng, C.-H., Chen, W.-F., Chu, C.-J., 2001. Origin and geological evolution of the Taipei Basin, Northern Taiwan. Western Pacific Earth Sciences 1-2, 115-142.

Waltham, T., 2002. Sinking cities-feature. Geology Today 18 (3), 95-100.

Wang, C.-Y., Sun, C.-T., 1999. Interpretation of seismic stratigraphy in the Taipei Basin (in Chinese with English abstract). Central Geological Survey Special Publication 11, 273-292.
Wang-Lee, C.-M., Cheng, Y.-M., Wang, Y., 1978. Geology of the Taipei Basin (in Chinese). Taiwan Mining Industry 30 (4), 350-380.

Wei, K., Chen, Y.-G., Liu, T.-K., 1998. Sedimentary history of the Taipei Basin with constraints from thermoluminescence dates. Journal of Geological Society of China 41, 109-125.

Wu, C.-M., 1987. Reviews on the land subsidence of the Taipei Basin (in Chinese). Sino-Geotechnics 20, 34-49.

Yeh, Y.-H., Barrier, E., Lin, C.-H., Angelier, J., 1991. Stress tensor analysis in the Taiwan area from focal mechanisms of earthquakes. Tectonophysics 200, 267-280.

Yu, S.-B., Chen, H.-Y., Kou, L.-C., Hou, C.-S., Lee, C.-F., 1999a. A study on the fault activities of the Taipei Basin (in Chinese with English abstract). Central Geological Survey Special Publication 11, 227-251.

Yu, S.-B., Kuo, L.-C., Punongbayan, R.S., Ramos, E.G., 1999b. GPS observation of crustal deformation in the Taiwan-Luzon region. Geophysical Research Letters 26 (7), 923-926.

Zang, S.X., Chen, Q.Y., Ning, J.Y., Zheng, K.S., Liu, Y.G., 2002. Motion of the Philippine Sea plate consistent with the NUVEL-1A model. Geophysical Journal International 150, 809-819. 